\title{
Anna Elżbieta Nieć \\ SZKODA W POWIERZCHNI ZIEMI JAKO SZKODA W ŚRODOWISKU \\ PRESSCOM, WrocŁaW 2017, ss. 240
}

Recenzowana monografia obejmuje zagadnienie szkód w powierzchni ziemi z intensywnością niespotykaną dotąd w nauce prawa. Autorka ze swadą prowadzi rozważania naukowe dotyczące uznania tych szkód w kontekście szkód w środowisku uwzględniając przede wszystkim najnowsze regulacje rangi ustawowej, wprowadzone do ustawy z dnia 27 kwietnia 2001 r. - Prawo ochrony środowiska w ramach jej dużej nowelizacji ustawą z dnia 11 lipca 2014 r. o zmianie ustawy - Prawo ochrony środowiska oraz niektórych innych ustaw ${ }^{1}$. Wzmiankowana nowelizacja wprowadziła do krajowego porządku prawnego zarówno nowe rozwiązania prawne wynikające z konieczności implementacji do krajowego porządku prawnego regulacji dyrektyw UE odnoszących się do zintegrowanej kontroli i zapobiegania zanieczyszczeniom, dyrektywy o emisjach przemysłowych, jak również przepisów Rozporządzenia Parlamentu Europejskiego i Rady (WE) nr 1272/2008 z dnia 16 grudnia 2008 r. w sprawie klasyfikacji, oznakowania i pakowania substancji i mieszanin, zmieniające i uchylające dyrektywy 67/548/EWG i 1999/45/WE oraz zmieniające rozporządzenie (WE) nr 1907/2006 i innych unijnych aktów prawnych.

Recenzowane opracowanie w sposób wyczerpujący prezentuje nie tylko dotychczasowe ustalenia jurysprudencji w przedmiotowym zakresie, ale zawiera także wątki dotąd nie analizowane, stanowiąc pierwsze na rynku wydawniczym kompleksowe i wyczerpujące opracowanie tematyki szkody w powierzchni ziemi per se oraz uznania tej szkody za szkodę w środowisku.

W recenzowanym opracowaniu szczególną uwagę poświęcono szkodom w powierzchni ziemi, przyjmując za podstawę rozważań tezę, że jest

1 Ustawa z dnia 11 lipca 2014 r. o zmianie ustawy - Prawo ochrony środowiska oraz niektórych innych ustaw, Dz. U. z 2014 r. poz. 1101. 
to jeden z kluczowych komponentów środowiska, który cechuje swoista niejednorodność, a co za tym idzie, wymaga on instrumentarium umożliwiającego jego skuteczną ochronę, zaś skutki działań wywołujących szkodę powinny być właściwie zdiagnozowane i naprawione w szczególnym reżimie ochronno-naprawczym. Trafnie uznała autorka, że składowe powierzchni ziemi, stanowią zarówno ukształtowanie terenu jak i gleba, a także ziemia i wody gruntowe - ponieważ: „Powierzchnia ziemi jako element środowiska złożony nie tylko z części mineralnych, lecz również materii organicznej, wody glebowej, powietrza glebowego i organizmów, podlega szczególnej ochronie, która uwzględniając racjonalne gospodarowanie powierzchnią ziemi, musi również zmierzać do zachowania funkcji środowiskowych, gospodarczych, społecznych i kulturowych tego komponentu", co determinuje istnienie owego instrumentarium, zarówno $\mathrm{w}$ odniesieniu wprost do gleb i powierzchni ziemi jak i środowiska wodno-gruntowego, co - należy podkreślić - stanowi nowość w krajowym porządku prawnym.

Dostrzec należy kwestię metodologiczną - autorka bowiem, z uwagi na odebrane wykształcenie, obejmujące nie tylko nauki prawne, ale i przyrodnicze, odniosła się merytorycznie także do kwestii prowadzenia pomiarów zanieczyszczenia powierzchni ziemi, prezentując szeroko metodyki prowadzenia badań zanieczyszczeń środowiska wodno-gruntowego i samej powierzchni ziemi w omawianym obszarze, ze swadą poruszając się po materiale normatywnym, którego źródło tkwi wszak w naukach przyrodniczych.

Za szczególnie cenne elementy merytoryczne opracowania uznaję również te, które odnoszą się do sposobu interpretacji nowych rozporządzeń wykonawczych, w tym zwłaszcza Rozporządzenia Ministra Środowiska z dnia 1 września 2016 r. w sprawie sposobu prowadzenia oceny zanieczyszczenia powierzchni ziemi ${ }^{2}$, z uwagi na całkowity brak literatury przedmiotu $\mathrm{w}$ tym zakresie. Warto podkreślić, że omawiane rozporządzenie zobowiązuje adresatów tych uregulowań do prowadzenia stosownych działań zmierzających do oceny wystąpienia zanieczyszczeń powierzchni ziemi w oparciu o nowe metodyki i w stosownej, wieloetapowej procedurze. W tym kontekście ubolewać należy, że równa uwaga nie została przyłożona do uregulowań zawartych w dwóch pozostałych nowo przyjętych rozporządzeniach, tj. Rozporządzeniu Ministra

2 Rozporządzenie Ministra Środowiska z dnia 1 września 2016 r. w sprawie sposobu prowadzenia oceny zanieczyszczenia powierzchni ziemi, Dz. U. z 2016 r. poz. 1395. 
Środowiska z 1 września 2016 r., w sprawie działań naprawczych ${ }^{3}$ i Rozporządzeniu Ministra Środowiska z dnia 1 września 2016 r. w sprawie rejestru szkód w środowiskư ${ }^{4}$, które jednak, choć budzą ciekawość recenzenta, stanowią mimo wszystko marginalny wątek dla całości prowadzonych przez autorkę rozważań.

Praca zbudowana jest z pięciu rozdziałów, wstępu i zakończenia, wykazu skrótów oraz wykazu źródeł. W pierwszym rozdziale zdefiniowano i scharakteryzowano pojęcie szkody, określono również jej przedmiotowy i podmiotowy zakres. Autorka dokonała podziału na szkody w środowisku sensu largo i sensu stricto. Wyodrębnienie tych dwóch kategorii przyjęto za podstawę do prowadzenia dalszych, szczegółowych rozważań i za narzędzie niezbędne do właściwej interpretacji i stosowania przepisów odnoszących się do szkód w środowisku. W rozdziale drugim scharakteryzowano powierzchnię ziemi jako immanentny komponent środowiska, przedstawiono również zakres ochrony, który przewidział ustawodawca względem tego elementu środowiska. Rozdział ten stanowi właściwe wprowadzenie do rozważań nt. szkody w powierzchni ziemi, w tym zarówno szkody $\mathrm{w}$ rozumieniu ustawy o zapobieganiu szkodom w środowisku i ich naprawie, jak i wyodrębnionej ze szkód sensu largo, szczególnej kategorii, jaką stanowią historyczne zanieczyszczenia powierzchni ziemi. Rozdział trzeci oscyluje wokół zagadnień związanych z charakterem prawnym i zakresem odpowiedzialności za szkodę w środowisku, w tym, w szczególności, szkodę w powierzchni ziemi, zaś - stanowiąca jego naturalną konsekwencję -zawartość rozdziału IV i V koncentruje się na problematyce obowiązku naprawienia szkody w środowisku (w szczególności w powierzchni ziemi) oraz remediacji.

Wobec tak ukształtowanego podziału treści podkreślić należy, że ma on charakter rozłączny i stanowi konsekwencję przyjętej w pracy metodyki badań, zaś sposób ukształtowania i podziału treści zmierza do realizacji założonych przez autorkę celów badawczych. W zakresie oceny stosowanego przez autorkę opracowania języka, podkreślić należy przede wszystkim precyzję wypowiedzi i staranność w edycji dzieła, w tym zwłaszcza precyzyjną terminologię języka prawnego i prawniczego.

3 Rozporządzenie Ministra Środowiska z dnia 1 września 2016 r. w sprawie działań naprawczych, Dz. U. z 2016 r. poz. 1396.

4 Rozporządzenie Ministra Środowiska z dnia 1 września 2016 r. w sprawie rejestru szkód w środowisku, Dz. U. z 2016 r. poz. 1398. 
Zgromadzony i obszernie wykorzystywany materiał źródłowy zasługuje na najwyższe uznanie. Staranność, z jaką autorka dokumentuje poszczególne etapy rozważań, wymagała ogromnego nakładu pracy. W wykazie literatury nie dostrzegłam braku żadnego z kanonicznych opracowań literatury przedmiotu koniecznych przy analizach tego rodzaju. Dodać należy, że autorka szeroko korzystała także z dorobku nauki prawa cywilnego, co w opracowaniach z zakresu prawa publicznego jest rzadkością a także - że jej obszerna wiedza przyrodnicza i powołane źródła z zakresu nauk przyrodniczych w żaden sposób nie zdominowały dzieła, stanowiącego wszak opracowanie z zakresu nauk prawnych. Podkreślić należy także bogactwo orzecznictwa wykorzystanego w pracy (w tym także sądów powszechnych!) i swadę, z jaką autorka wykorzystuje je na poparcie swych tez.

Podsumowując uznać należy, że recenzowane opracowanie z pewnością można określić jako monograficzne, a więc wyczerpująco traktujące dane zagadnienie. Na uwagę zasługuje zwłaszcza praktyczny profil opracowania, jego aktualność i walor nowości, a także biegłość, z jaką autorka porusza się $\mathrm{w}$ prezentowanej tematyce. Za wielką zaletę dzieła uważam jego walor praktyczny, a więc możliwość wykorzystania dokonanych w recenzowanym dziele ustaleń przez praktyków stosujących przepisy ustawy Prawo ochrony środowiska po nowelizacji z 2014 r., wprowadzającej obowiązki związane nie tylko z oceną szkód występujących w powierzchni ziemi, ale także z nowym instrumentem prawnym ochrony powierzchni ziemi, który stanowi remediacja.

rec. Anna Haładyj*

* Dr hab., prof. Katolickiego Uniwersytetu Lubelskiego Jana Pawła II. 